\title{
Structure and supposed feeding mechanisms of the plasmodium of Intoshia linei (Orthonectida)
}

\author{
G.S. Slyusarev, A.S. Cherkasov \\ Department of Invertebrate Zoology, Faculty of Biology and Soil Science, St. Petersburg State \\ University, Universitetskaja nab. 7/9, St. Petersburg, 199034 Russia. \\ e-mail: slyusarev@hotmail.com
}

ABSTRACT: The parasite plasmodium of orthonectid Inthoshia linei is covered with 2 distinct membranes. Plasmodium bears microvilli in some regions. A highly developed tubular network resembling smooth endoplasmic reticulum is considered to be a part of a permanent pinocytotic complex. Phagocytosis and pinocytosis both are supposed to be the mechanisms of plasmodium feeding.

KEYWORDS: Orthonectida, plasmodium, phagocytosis, pinocytosis.

\section{Строение и возможный механизм питания плазмодия Intoshia linei (Orthonectida)}

\section{Г.С. Слюсарев, А.С. Черкасов}

\author{
Кафедра зоологии беспозвоночных, биолого-почвенный факультет, Санкт-Петербургский \\ государственныйуниверситет, Университетская набережная 7/9, Санкт-Петербург 199034, \\ Россия. \\ e-mail: slyusarev@hotmail.com
}

РЕЗЮМЕ: Плазмодий ортонектиды Intoshia linei покрыт двумя отчетливо различимыми мембранами. На отдельных участках плазмодий несет микровилли. Сильно развитая тубулярная сеть, напоминающая гладкий эндоплазматический ретикулюм, является частью постоянного пиноцитозного комплекса. Процесс питания плазмодия у I. linei осуществляется как при помощи фагоцитоза, так и пиноцитоза.

КЛЮЧЕВЫЕ СЛОВА: Orthonectida, плазмодий, фагоцитоз, пиноцитоз.

Orthonectida is a poorly known group of lower Metazoa. Phylogenetic relationships of Orthonectida remain uncertain (Hatschek, 1888; Hartmann, 1925; Stunkard, 1954; Pawlowski et al., 1996; Hanelt et al., 1996; Westheide, Rieger 1996). Orthonectids are the parasites of a wide range of marine invertebrates. Orthonectid life cycle includes a free-living sexual stage and a parasitic stage, commonly referred to as plasmodium. The males and females develop from germinal cells within the plasmodium and copulate after leaving the host. Fertilized eggs give rise to the ciliated larvae developing within the female. After releasing, the larvae infect a new host (Caullery, Lavallee, 1912; Caullery, 1961).

The origin of orthonectid plasmodium is not clear. Metschnikoff (1881), who suggested this term, and many authors after him considered the plasmodium to be a stage of life cycle of a parasite. According to Kozloff(1994, 1997), the plasmodium is not an individual parasitic organism but a huge host cell (cells) transformed by parasites. The morphology of orthonectid plas- 
modium is poorly known. Only three species have been studied at the ultrastructural level (Kozloff, 1969, 1971, 1994, 1997; Slyusarev, Miller, 1998). With the exception of general considerations nothing is known about the way of feeding in the othonectid plasmodium. The present study provides the structure and supposed feeding mechanisms of the plasmodium of orthonectid Inthoshia linei.

\section{Material and methods}

Orthonectid Intoshia linei (Giard, 1877) is a parasite of the nemertine Lineus ruber (Mueller, 1774). The nemertines were collected in August 2001 from the Barents Sea in the region of the former marine biological station Dalnie Zelentsi point $\left(69^{\circ} 07^{\prime} \mathrm{N}, 36^{\circ} 05^{\prime} \mathrm{E}\right)$. The hosts were collected during the low tide and kept in Petri dishes. Five nemertines infected with plasmodium were found and all of them were dissected and examined. Pieces of infected nemertines were fixed in $4 \%$ glutaraldehyde with 0.1 $\mathrm{M}$ cacodylate buffer, $\mathrm{pH}$ 7.3. After the rinse in $6.85 \%$ sucrose solution for $1 \mathrm{~h}$, the pieces were transferred into $1 \% \mathrm{OsO}_{4}$ with the same buffer, also for $1 \mathrm{~h}$. After fixation the material was rinsed in $0.1 \mathrm{M}$ cacodylate buffer, dehydrated in ethanol, and embedded in Epon 812. ReichertJung Ultracut $E$ was used to make sections for TEM microscopy. The sections were examined in JEOL 100SX transmission electron microscope.

\section{Results}

The mature plasmodium of I. linei is mainly associated with loose connective tissue of the host. The plasmodium can be found in gonads and muscles but it never penetrates the digestive system. Plasmodium is characterized by an irregular outline and forms numerous offshoots. It should be noted that the young plasmodium is tightly adjacent to the host tissues while the mature one is surrounded with lacunae (Fig. 1A).

Two membranes are on the surface of the parasite plasmodium (Figs 1B, C). The surface of the plasmodium is smooth in some places, but in the others, it bears microvilli (Figs 1A, 2B, C). Some microvilli may protrude into the host tissue or into lacunae, while the others are parallel to the surface of the plasmodium (Figs 1A, 2C). Microvilli are approximately $0.7 \mathrm{~mm}$ in length and $0.2 \mathrm{~mm}$ in diameter. A highly developed tubular network resembling smooth endoplasmic reticulum was found in some regions (Fig. 1A). This network is always associated with the area adjacent to the external membrane of the plasmodium. Sometimes, pinocytotic vesicles are visible at the foot of microvilli (Fig. $2 \mathrm{C})$. They occur also in the regions with smooth surface. It should be emphasized that pinocytotic vesicles are associated with the tubular network mentioned above.

Formation of phagosomes is quite evident in a great number of sections (Fig.1B). Microvilli are always absent in the areas where phagocytosis is observed. It is noteworthy that newly formed large vacuoles are always covered by 3 membranes: two plasmodium membranes and one host cell's membrane (Fig. 1B). The large phagosome content seems to be highly homogeneous. The plasmodium cytoplasm is filled with smaller vacuoles of different size and content, some of them being food vacuoles. The smaller food vacuoles are surrounded with one or two membranes only (Figs 1B, 2A).

\section{Discussion}

Kozloff (1997) does not mention double membrane surface structure in Ciliocincta sabellariae plasmodium, however, two membranes are perfectly seen on fig. $3 \mathrm{~b}$ of the above cited publication. The same is true for the plasmodium of I. variabili. Judging by TEM micrographs, it is surrounded with two membranes (Slyusarev, Miller, 1998). Thus, two membranes are found on the external surface of the parasite plasmodium in all orthonectids studied so far.

Microvilli on the plasmodium surface are found in I. variabili (Slyusarev, Miller, 1998), as well as in Rhopalura ophiocomae and Ciliocincta sabellaria (Kozloff, 1994, 1997). In all mentioned species, plasmodium bears microvilli in some separate parts only. 


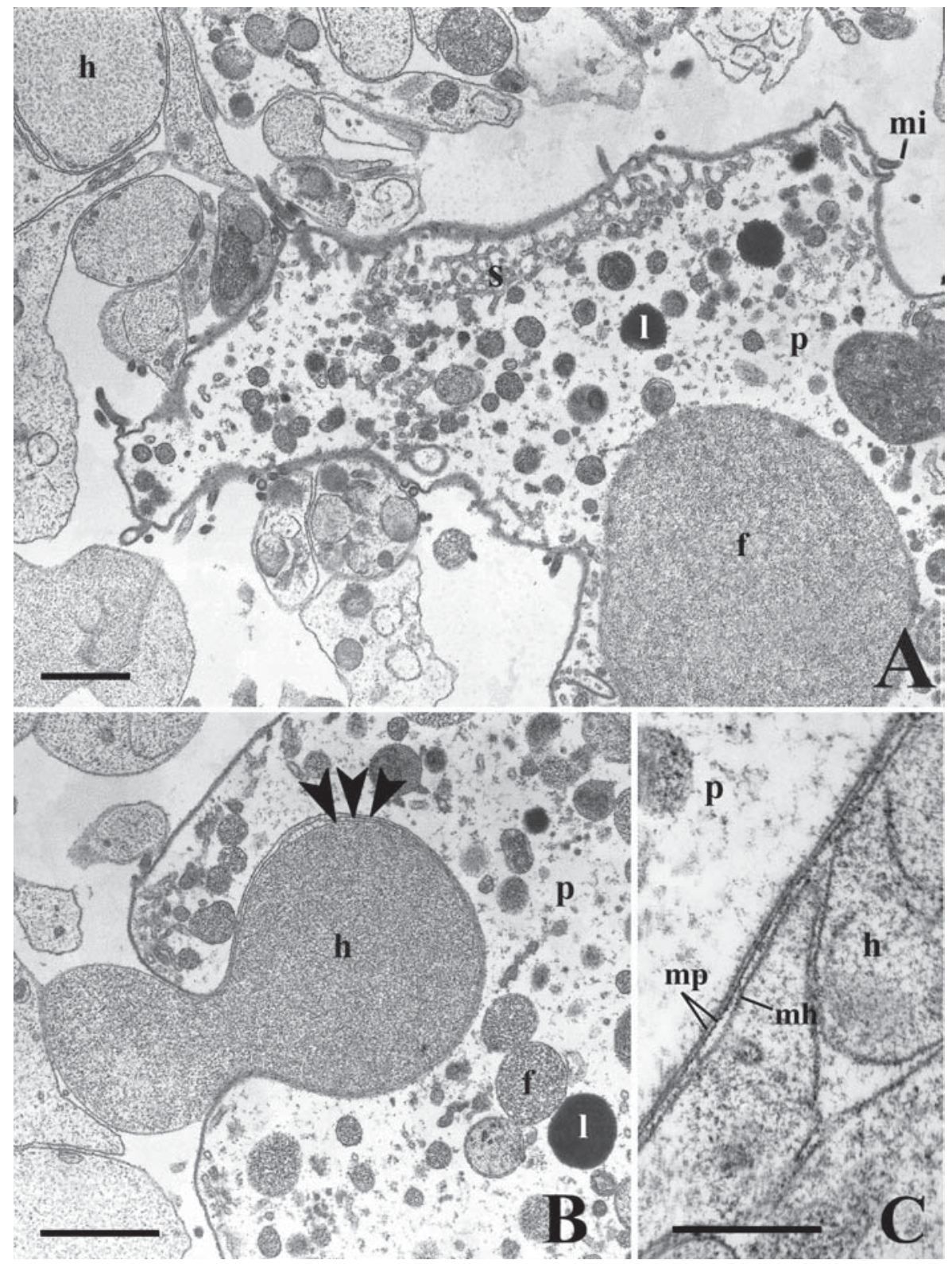

Fig. 1. Mature plasmodium of Intoshia linei.

A - plasmodium offshoot with well developed pinocytotic complex, B - formation of phagosome, C - boundary between the plasmodium and host tissues. Abbreviations: 1 - lipid granule, $\mathrm{h}$ - host tissue, $\mathrm{f}$ - phagosomes, $\mathrm{mh}$ membrane of host cell, mi - microvilli, $\mathrm{mp}$ - membrane of plasmodium, $\mathrm{p}$ - plasmodium cytoplasm, $\mathrm{s}$ - tubular network. Arrowheads show 3 membranes in the wall of the forming phagosome. Scale bars: A $-0.2 \mathrm{~mm}, \mathrm{~B}-0.2 \mathrm{~mm}$, $\mathrm{C}-0.3 \mathrm{~mm}$.

Рис. 1. Зрелый плазмодий Intoshia linei.

A - вырост плазмодия с хорошо развитым пиноцитозным комплексом, В - образование фагосомы, С граница между плазмодием и тканями хозяина. Обозначения: 1 - липидная гранула, $\mathrm{h}$ — ткани хозяина, $\mathrm{f}-$ фагосома, $\mathrm{mh}$ - мембрана клетки хозяина, mi - микровилли, $\mathrm{mp}$ - мембрана плазмодия, $\mathrm{p}$ - цитоплазма плазмодия, $\mathrm{s}$ - тубулярная сеть. Наконечники стрелок указывают на 3 мембраны в стенке формирующейся фагосомы. Масштаб: А - 0,2 мкм, В - 0,2 мкм, $\mathrm{C}-0,3$ мкм. 

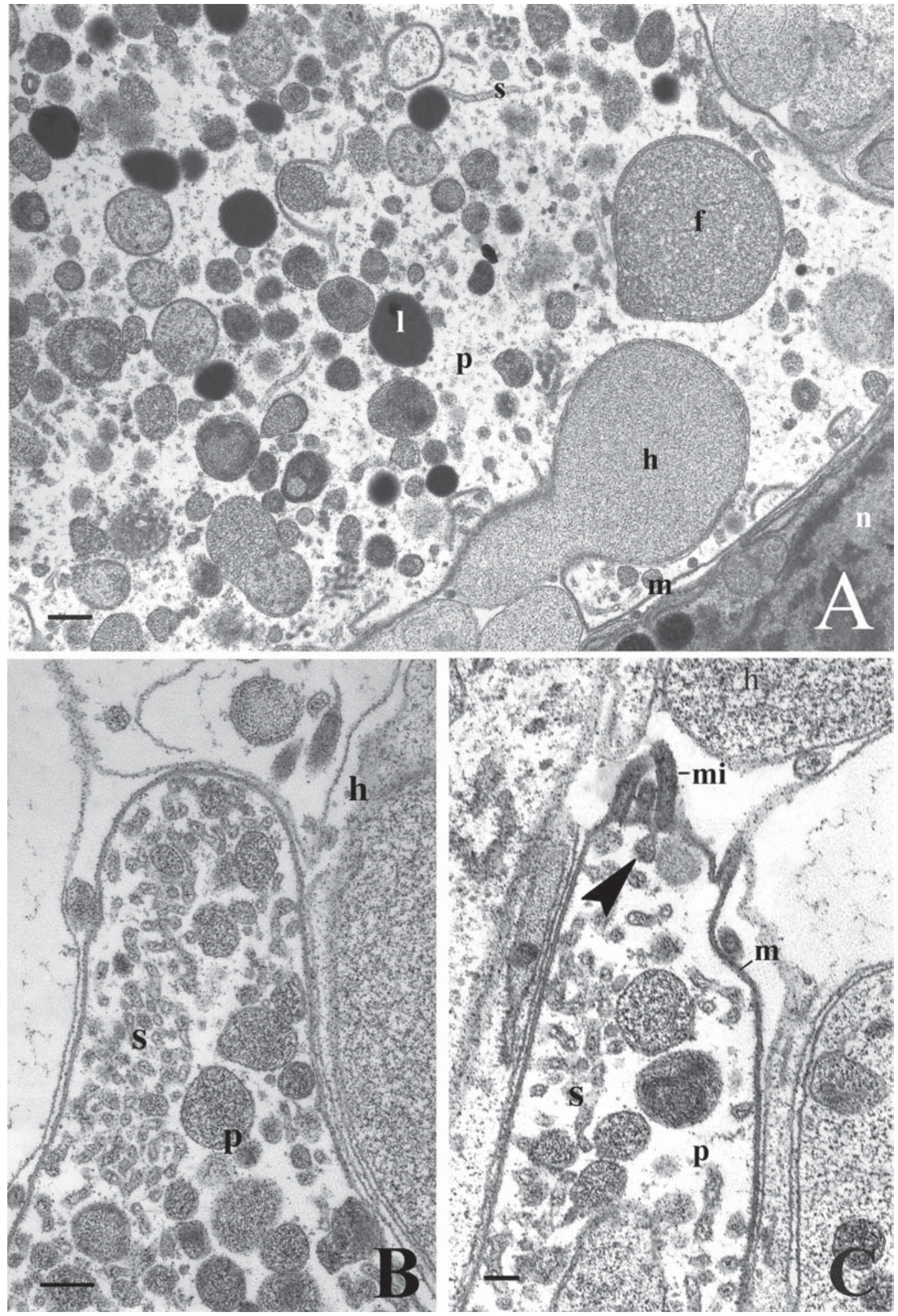
The presence of a well developed tubular network close to the plasmodium surface can be regarded either as smooth endoplasmic reticulum or a permanent pinocytotic complex. Our data provide evidence that pinocytosis and phagocytosis both are the feeding mechanisms of mature plasmodium of I. linei. The plasmodium seems to be using both feeding strategies simultaneously.

The surface structure of the orthonectid plasmodium heavely resembles the plasmodium of some myxosporidia which is also covered with two membranes and bears microvilli (Uspenskaya, 1966, 1984). The feeding strategy of the orthonectid plasmodium seems also to be similar to that of myxosporidian plasmodia(Uspenskaya, 1966, 1984). It may be considered to be an indirect argument for that the plasmodium is an individual organism, but not a transformed host cell (tissue), as Kozloff (1994, 1997) believed.

\section{Acknowledgements}

The main financial support for this study was provided by grant RFFI \# 04-07-00192.

\section{Literature}

Caullery M. 1961. Classe des Orthonectides (Orthonectida Giard, 1877) // P.-P. Grasse (ed.). Traité de Zoologie. Paris: Masson. T.4. Fasc.1. P.695-706.

Caullery M., Lavallee A. 1912. Recherches sur le cycle évolutif des orthonectides. - Les phases initiales dans l'infection expérimentale de l'ophiure,Amphiura squamata, par Rhopalura ophiocomae Giard // Bulletin Scientifique de la France et de la Belgique. T.46. P.139-171.
Hanelt B., Van Schyndel D., Adema C. M., Lewis L. A., Loker E. S. 1996. The phylogenetic position of Rhopalura ophiocomae (Orthonectida) based on 18S ribosomal DNA sequence analysis // Molecular Biology and Evolution. Vol.13. No.9. P.1187-1191.

Hartmann D.W. 1925. Mesozoa // Handbuch der Zoologie. W.Kükenthal, Th.Krumbach (Hrg.). Berlin, Leipzig: Walter de Gruyter. Bd.1. S.996-1014.

Hatschek B. 1888. Lehrbuch der Zoologie. Jena: Gustav Fischer. $432 \mathrm{~S}$.

Kozloff E.N. 1969. Morphology of the orthonectid Rhopalura ophicomae // Parasitology. Vol.55. P.171-195.

Kozloff E.N. 1971. Morphology of the orthonectid Ciliocincta sabellariae // Parasitology. Vol.57. P.585-597.

Kozloff E.N. 1994. The structure and origin of the plasmodium of Rhopalura ophiocomae (Phylum Orthonectida) // Acta Zoologica (Stockholm). Vol.75. P.191-199.

Kozloff E.N. 1997. Studies on the so-called plasmodium of Ciliocincta sabellariae (Phylum Orthonectida), with notes on an associated microsporan parasite // Cahiers de Biologie Marine. T.38. P.151-159.

Metschnikoff E. 1881. Untersuchungen über Orthonectiden // Zeitschrift für wissenschaftliche Zoologie. Bd.35. P.282-303.

Pawlowski J., Montoya-Burgos J.-I., Fahrni J. F., Wuest J., Zaninetti L. 1996. Origin of the Mesozoa inferred from 18S rRNA gene sequences // Molecular Biology and Evolution. Vol.13. No.8. P.1128-1132.

Slyusarev G.S., Miller D.M. 1998. Fine structure of the mature plasmodium of Intoshia variabili (Phylum Orthonectida), a parasite of the plathelminth Macrorhynchus crocea // Acta Zoologica (Stockholm). Vol.79. P.319-328.

Stunkard H.W. 1954. The life-history and systematic relations of the Mesozoa // The Quarterly Review of Biology. Vol.29. P.230-244.

Uspenskaya A.V. 1966. On the mode of nutrition of vegetative stages of Myxidium lieberkuhni (Butschli) // Acta Protozoologica. Vol.4. P.81-89.

Uspenskaya A.V. 1984. [Cytology of Myxosporidia]. Leningrad: Nauka Publ. 145 p. [in Russian].

Westheide W., Rieger R.M. 1996. Spezielle Zoologie. Stuttgart: G. Fischer. 909 S.

Fig. 2. Phagocytosis and pinocytosis in mature plasmodium of Intoshia linei.

A - plasmodium cytoplasm with granules, B - phagocytosis, $\mathrm{C}$ - pynocytosis. Abbreviations: 1 - lipid granule, $\mathrm{h}$ — host tissue, $\mathrm{f}$ - phagosome, $\mathrm{m}$ - plasmodium membranes, $\mathrm{mi}$ - microvilli, $\mathrm{n}$ - host cell nucleus, $\mathrm{p}$ - plasmodium cytoplasm, $\mathrm{s}-$ tubular network. Arrowhead shows the putative pinocytotic vesicle. Scale bars: A $-0.2 \mathrm{~mm}, \mathrm{~B}-0.2$ $\mathrm{mm}, \mathrm{C}-0.3 \mathrm{~mm}$.

Рис. 2. Фагоцитоз и пиноцитоз в зрелом плазмодии Intoshia linei.

A - цитоплазма плазмодия с различными гранулами, В - фагоцитоз, С - пиноцитоз. Обозначения: 1 липидная гранула, $\mathrm{h}$ - ткани хозяина, $\mathrm{f}$ - фагосома, $\mathrm{m}$ - мембраны плазмодия, $\mathrm{mi}$ - микровилли, $\mathrm{n}$ - ядро клетки хозяина, $\mathrm{p}$ - цитоплазма плазмодия, $\mathrm{s}$ - тубулярная сеть. Наконечник стрелки указывает на предполагаемый пиноцитозный пузырек. Масштабы: А - 0,2 мкм, В - 0,2 мкм, C - 0,3 мкм. 